\title{
On the Seedling Structure of certain Centrospermae.
}

\author{
BY
}

T. G. HILL,

Assistant Professor of Botany; University of London; University College,

AND

\author{
ETHEL DE FRAINE, \\ University of London; University College.
}

With eight Figures and seven Diagrams in the Text.

$\mathrm{T}$ HE study of the seedlings of the Centrospermae ${ }^{1}$ has resulted in no very striking results, the chief features of interest being connected more especially with the Natural Order Nyctaginaceae.

Unfortunately, we were unable to procure seeds of the Natural Orders Basellaceae, Batidaceae, and Cynocrambaceae, so that we have no information to offer regarding the structure of their seedlings. The same remarks also apply to certain genera of the other Natural Orders of the Cohort, but sufficient of the rest have been examined to give a general idea of the seedling anatomy of those orders centring around the Phytolaccaceae.

The characteristic mode of transition of the Centrospermae is Van Tieghem's type 3, and although this has been described in previous papers it appears desirable to draw attention to its features in one example, Calandrinia Menziesii, in order that much repetition, when dealing with the different plants, may be avoided.

\section{PORTULACACEAE.}

Calandrinia Menziesii, Torr. et Gray. The seedlings of this plant are very small, with fleshy cotyledons which show no internal differentiation into palisade tissue. In this species, and also in $C$. amoena, C. speciosa, C. umbellata, and C. grandiflora, a short cotyledonary tube is present. Each seed-leaf, which in transverse section is circular in outline, has in its upper part three bundles, one central and two lateral, of which the former is the largest. Tracing these strands downwards, the central one soon shows

1 T. G. Hill : On the Seedling Structure of certain Centrospermae. Brit. Assoc. Rep., Sect. K, York, 1906.

[Annals of Botany, Vol. XXVI. No. CI. January, 1912.] 
signs of bifurcation; the phloem divides into two parts which gradually move away from one another so that the appearance of the strand, as viewed in transverse section, is like the letter $\mathrm{V}$, the protoxylem being situated at the apex (Diagram I, Fig. 2). This apparent movement is continued, hence the $\mathrm{V}$ becomes widely opened and the protoxylem comes into a central position and is bounded on each side by metaxylem and phloem; in other words, the bundle is bicollateral (Diagram I, Fig. 3). Whilst these changes have been taking place, the lateral strands have gradually approached the central bundle, and finally they fuse with it. The condition now obtaining

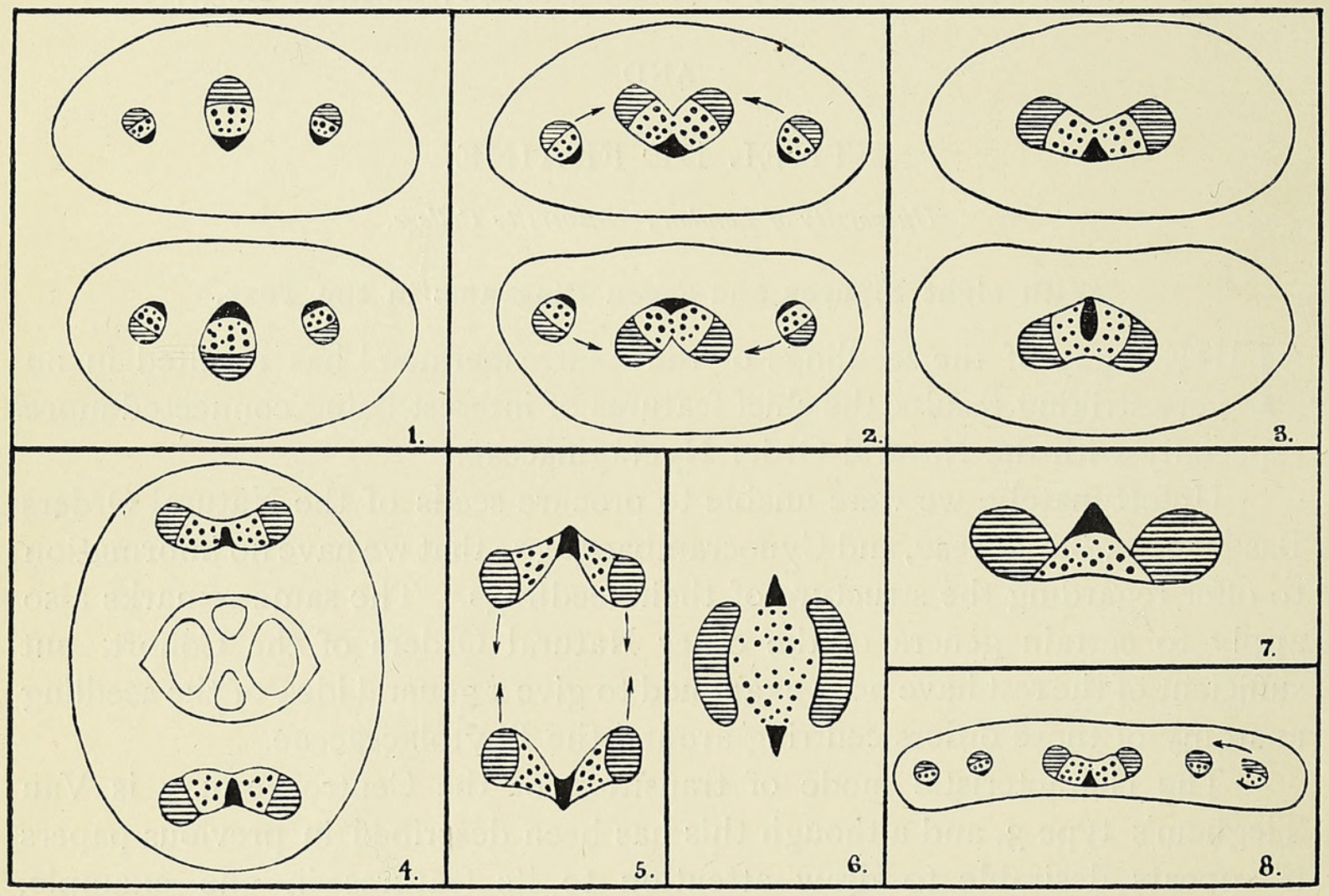

Diagram I. Figs. I-7 Calandrinia, Fig. 8 Portulaca. In this and in the following diagrams the protoxylem is indicated by black areas, the metaxylem by round or elongated dots, and the phloem by shading.

is seen in the third figure of Diagram $\mathrm{I}$, which arrangement is maintained for some distance downwards. The seed-leaves, which have no marked petiole, fuse laterally to form a short tube; at the cotyledonary node the cotyledontraces are seen to have their protoxylems situated well towards the periphery, full exarchy being arrived at during the somewhat rapid passage towards the centre of the hypocotyl. In the axis a general centripetal displacement occurs and, concurrently, the opposing groups of phloem and metaxylem move towards each other and effect a junction (Diagram I, Figs. 5 and 6); thus a diarch root-structure is organized. With regard to the fundamental transition phenomena, it will be observed that one bundle enters the axis from each cotyledon; each of these strands bifurcates and rotates so that 
the protoxylem is brought into the exarch position but still remains in the plane of the cotyledons; finally, the two groups of phloem- and of metaxylemelements of one cotyledonary bundle fuse with the corresponding tissues of the other cotyledon, the resulting strands being situated in the intercotyledonary plane. A diarch root-structure is thus formed.

This is Van Tieghem's third type of transition, and it will be referred to in the following pages as type 3 .

Calandrinia speciosa shows no important feature of difference from C. Menziesii.

Calandrinia amoena, Vis., in all essentials is identical with C. Menziesii; the cotyledons, however, are not so rounded and the bifurcation of their central bundles does not take place at so high a level.

Calandrinia grandiflor a, Lindl., is chiefly remarkable from the fact that the rearrangements of the cotyledonary strands are more complete at a higher level than in any of the other species of the genus examined, the rotation of the bifurcated bundle being carried so far that the two groups of metaxylem elements are closed up, with the protoxylem in the exarch position, at a level just above the cotylar tube (Diagram I, Fig. 7). This feature is also shared by $C$. umbellata, although not in so marked a degree.

Claytonia perfoliata, Don. The main features of dissimilarity between the transition phenomena in the very small and slender seedlings of this plant and those of species of Calandrinia are that the two lateral bundles of each seed-leaf of Claytonia early fuse with the larger central one; the main cotylar bundles are endarch and collateral through the whole length of the seed-leaf; and, finally, the vascular rearrangements which take place in a very short vertical distance leading to the diarch root-structure occur during the passage of the seed-leaf-traces from the cotyledons to the central region of the axis and in the upper part of the hypocotyl.

Portulaca oleracea, L. The seedling is very small and its cotyledons are much flatter than those of any of the preceding plants. The seed-leaves have several bundles in their blades, one large central one with two or three smaller strands on each side. The latter fuse on to the main central bundle, which shows bifurcation and rotation before the last of the laterals have effected a junction with it in the basal region of the blade (Diagram I, Fig. 8). The transition is of type 3 and closely resembles that of Calandrinia umbellata.

\section{CARYOPHYLLACEAE.}

SILENOIDEAE.

Cucubalus baccifera, $\mathrm{L}$. The transition resembles that of the foregoing plants in following type 3. Of the differences, relatively unimportant, which obtain between Cucubalus and Calandrinia for example, the following are 
the more striking: in the former plant, as in Claytonia, the lateral strands of each cotyledon fuse on to the larger central bundle in the upper region of the petiole before any vascular rearrangement is inaugurated in the median bundle; this strand, in transverse section, appears like a widely opened $U$ with the xylem-elements, situated on the concave side, well dispersed owing to the development of much parenchyma, the presence of which makes it difficult to trace the movements of the protoxylem ; finally, no cotyledonary tube is formed. As in the majority of the foregoing plants, the vascular rearrangements begin in the petioles of cotyledons, but in the basal rather than in the upper regions.

Lychnis Viscaria, L. The transition phenomena resemble those of Cucubalus; the central bundle of each cotyledon is, however, very small in Lychnis and the vascular rearrangements are more ill defined. A cotyledonary tube is formed.

Lychnis Githago. According to Gerrard ${ }^{1}$ the transition follows the same course as in Silene inflata.

Silene inflata follows type 3. From Gérard's account it appears that the transition phenomena commence in the upper regions of the petioles of the seed-leaves, but at a level just above the cotyledonary node the bifurcated bundles again close up. This is in accordance with our observations on S. pendula.

Silene pendula, L., shows no features of particular interest; the transition follows type 3 , and the bifurcation of the main cotylar strand begins in the petioles of the seed-leaves before all the small laterals have fused with it. On tracing these half-bundles downwards, they are seen gradually to close up so as partly to sandwich the protoxylem-elements between them; thus at the cotyledonary node these bundles are closely apposed with the protoxylem towards the exarch position. There is a well-marked cotylar tube.

Silene Otites, Sm., closely resembles S. pendula.

Silene Schafta, Gmel ex Hohen., does not differ in any important feature from S. pendula. The bifurcation begins at a relatively high level in the cotyledons, and the lateral strands unite with the adjacent portions of the divided central bundles at about the same level.

Another example showed the unusual feature of a triarch root. The changes which led to this were as follows. One cotyledon was normal in having in the base of its blade one large central bundle and two small lateral ones; the other had two central ones and two laterals. The lateral

1 Gérard: Recherches sur le passage de la racine à la tige. Ann. Sci. Nat., Bot., sér. 6, t. xi, 1880 . 
strands fused on to the central ones, which in the petiole bifurcated and rotated in the usual way (Diagram 2, Figs. I and 2). In the case of the cotyledon $c .2$ there are thus two pairs of phloem-masses and two groups of protoxylem-elements. Fusion takes place between the phloems which lie side by side, and the resulting strand remains in position, whilst the other two rotate inwards (Diagram 2, Fig. 3). The completion of these rearrangements in the axis results in a triarch ront-structure (Diagram 2, Figs. 4. and 5).

Dianthus barbatus, L. The mode of transition is that of type 3 . The lateral bundles in the base of the blade of the seed-leaves fuse on to the central bundles so that one strand only occurs in each cotyledon petiole. Although these bundles commence their division at the top of the cotyledonary tube, the major part of the transition takes place during the inward

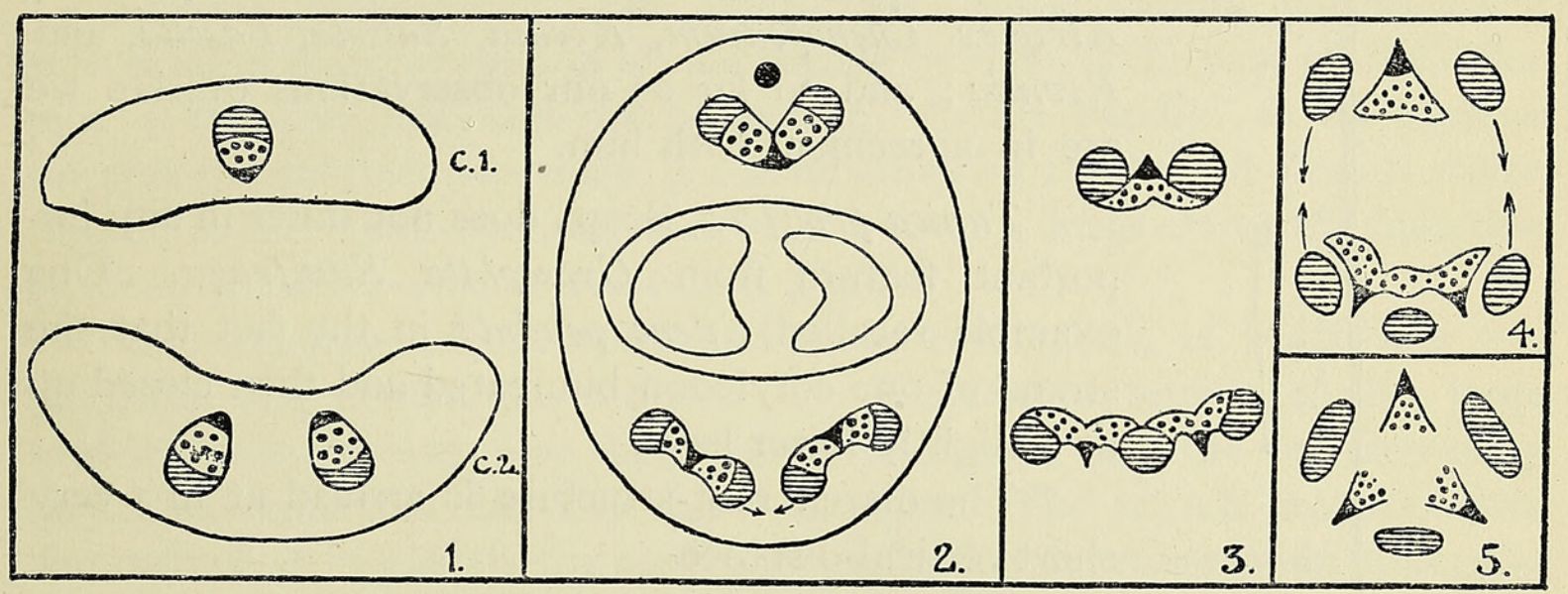

Diagram 2. Silene Schafia.

passage of these strands to the centre of the axis, and in the upper part of the hypocotyl.

Dianthus chinensis, L., differs from $D$. barbatus in two features: the main bundle of each seed-leaf commences its vascular rearrangements in the base of the blade before the lateral strands have joined on to it; also, the protoxylem of each seed-leaf-trace becomes completely exarch during its passage down the short but well-marked cotyledonary tube.

Dianthus arenarius, L., resembles D. barbatus very closely.

Gypsophila Saxifraga, L. The third type of transition is followed, and the vascular rearrangements begin in the base of the seed-leaves on a level with the top of the cotyledonary tube. The main changes take place in the upper part of the hypocotyl as in D. barbatus.

Saponaria cerastoides, Fisch. ex C. A. Mey. (Fig. I, B), does not differ in any essential feature from Gypsophila Saxifraga, with the exception that a cotyledonary tube is not formed. 
Saponaria Vaccaria, L. (Fig. I, A), shows a few points of difference when compared with $S$. cerastoides. S. Vaccaria has much larger seedleaves and a well-marked cotyledonary tube; also the petioles of the cotyledons each have three bundles, a main central one with a lateral on each side, which do not fuse until just above the cotyledonary node. Although the transition takes place as in Gypsophila and Dianthus barbatus, it is inaugurated at a lower level, namely at the base of the cotyledonary tube.

Saponaria vulgaris is practically identical with S. Vaccaria as regards the phenomena under discussion; the vascular changes, however, are

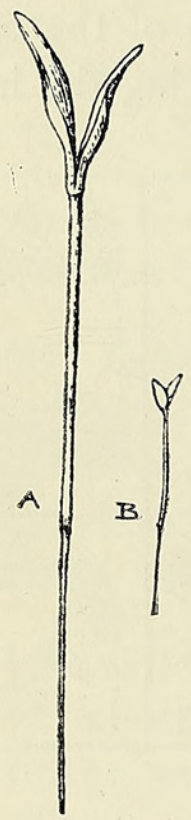

FIG. I. A. Saponaria Vaccaria: B. S. cerastoides. Natural size. initiated at a slightly higher level than in $S$. Vaccaria.

Dangeard ${ }^{1}$ has pointed out the similarity in the essentials of the seedling anatomy of Saponaria, Atriplex, Chenopodium, Kochia, Salsola, Basella, and Rivinia; and so far as our observations overlap we are in agreement with him.

Tunica prolifera, Scop., does not differ in any important feature from Gypsophila Saxifraga. One example recalled Silene pendula in the fact that the strand of one cotyledon bifurcated and then closed up at a slightly lower level.

The diarch root-structure is arrived at in a very short vertical distance.

ALSINOIDEAE.

Cerastium perfoliatum, L. The transition phenomena are practically identical with those of Dianthus barbatus; there is, however, in $C$. perfoliatum no cotyledonary tube, and the separation of the phloem-masses of the bifurcated seed-leaf-traces is more marked.

Stellaria graminea, L., also closely resembles Dianthus barbatus. Unlike Cerastium perfoliatum, S. graminea has a short cotyledonary tube.

Spergularia salina, J. et C. Presl., ${ }^{2}$ does not differ in any essential feature from Dianthus barbatus, the chief point of dissimilarity being in the fact that in $S$. salina the vascular rearrangements start at a higher level and the cotyledonary bundles enter the axis in a more advanced state of division and rotation.

Spergula arvensis, L., has a larger seedling than Spergularia salina, and its vascular rearrangements recall those of Calandrinia Menziesii; thus,

1 Dangeard : Recherches sur le mode d'union de la tige et de la racine chez les Dicotylédones. Le Botaniste, i, 1889 .

2 This may possibly be S. rubra, J. et C. Presl. 
unlike Spergularia salina, the central bundle of each cotyledon bifurcates before the lateral strands have effected a junction with it, and this beginning of the transition phenomena takes place high up in the seed-leaf.

Polycarpon tetraphyllum, L., closely resembles Spergula arvensis. A cotyledonary tube is formed.

Corrigiola litoralis, L. The seed-leaves do not form a tube at their base. The resemblance to Spergula arvensis is very close.

\section{AMARANTACEAE.}

AMARANTOIDEAE.

Celosia cristata, L., C. plumosa, ?, and C. spicata, Spreng. The transition phenomena in these three seedlings are almost identical with those of Calandrinia grandiflora. The bifurcation of the central cotyledonary strand takes place at the top of the petiole or even in the base of the foliar part of the seed-leaf, and the so-formed 'double bundle', in its passage towards the cotyledonary node, is accompanied by two lateral strands which fuse on to the divided central bundle at a level a little above the insertion of the seed-leaves which do not form a tube.

One example of $C$. spicata had three cotyledons, of which one was markedly larger than the other two. The central bundle of this large seed-leaf was more massive than that of the others, and the corresponding pole of the root was similarly much stronger. The triarch root-structure was arrived at in exactly the same way as the diarch arrangement in normal dicotyledonous specimens.

Amaranthus caudatus, L. The vascular re-arrangements closely resemble those of Celosia. The central cotyledonary strands bifurcate in the blades of the seed-leaves and the protoxylems are fully exarch at the cotyledonary node. Also, as in Celosia, the lateral strands join on to the median bundle at a level just above the insertion of the seed-leaves. The only point of dissimilarity from Celosia lies in the fact that in $A$. caudatus the four groups of phloem-elements in the upper region of the hypocotyl derived from the two seed-leaf-bundles may postpone their union for some distance downwards; similar observations have been made in some Cactaceae.

Amaranthus abyssinicus, ?, A. Dussii, Spreng., A. hypochondriacus, L., $A$. paniculatus, L. - which has also been investigated by Gérard, ${ }^{1}$ with whose observations we are in agreement-and $A$. viridis all closely resemble Amaranthus candatus.

Amaranthus sylvestris, Desf., is remarkable chiefly from the fact that not only do the central seed-leaf-bundles bifurcate and rotate in the blades 
of their respective cotyledons, but they divide completely into two, leaving protoxylem elements isolated between them, a feature which is characteristic of Phytolacca, Allionia, Mirabilis, and other Nyctaginaceae ; also it occurs in some species of Lupinus and Dahlia. A minor point to be remarked upon in Amaranthus sylvestris is that the union of the laterals with the central bundles of the cotyledons is effected at a much higher level than in A. caudatus, \&c.

Pupalia purpurea, unlike any of the foregoing species of Amaranthus, does not show an early inauguration of the transition phenomena; in fact the bundle from each cotyledon enters the axis in an undivided endarch condition, all the changes leading to the formation of a diarch root-structure taking place rapidly in the upper part of the hypocotyl.

GOMPHRENOIDEAE.

Gomphrena haageana, Klotzsch, resembles Amaranthus sylvestris in the division of the central cotyledonary bundles and isolation of protoxylem elements in the blade of the cotyledon. A feature of difference is found in the fact that one of the laterals may delay fusion with the adjacent half of the central strand until the upper region of the hypocotyl is reached.

Gomphrena globosa, L., is, in essentials, identical with G. haageana; the isolation of the protoxylem, however, is not so well marked as in the latter plant. In both species a cotyledonary tube is formed, a point of difference from Amaranthus and Celosia.

\section{CHENOPODIACEAE.}

The anatomy of the seedlings of this Order has formed the subject of investigations by previous authors. Van Tieghem ${ }^{1}$ has remarked upon the occurrence of diarchy in the primary roots of Beta vulgaris, Spinachia oleracea, and Atriplex hortensis.

Gérard ${ }^{2}$ has shown that the transition of Atriplex hastata follows that of type 3 , and that it is not by any means rapid.

The work of Dangeard ${ }^{3}$ in this connexion has already been alluded to ; it may, however, be further remarked that he considers that the venation of the cotyledons has an important bearing on the primary root-structure and concludes that the seed-leaves with pinnate venation have a diarch root, whilst those with a palmate venation have a tetrarch root-structure.

Fron ${ }^{4}$ has made the, hitherto, most extensive study of the seedling anatomy of this Natural Order, and points out that the structure of Atriplex hastata is typical for the genus. He also draws attention to the similarity

\footnotetext{
1 Van Tieghem: Recherches sur la symétrie de structure des plantes vasculaires. Ann. Sci. Nat., Bot., sér. 5 , t. xiii, I870. loc. cit.

4 Fron: Recherches anatomiques sur la racine et la tige des Chénopodiacées. Ann. Sci. Nat., Bot., sér. 8, t. ix, 1899 .
} 
between Salsola Kali, S. Soda, S. vermiculata, Sucieda, Chenopodium, Blitum, Roubiera, and Beta. He concludes that the transition in the Chenopodiaceae takes place at different levels of the hypocotyl : at the lower end in Atriplex, Salsola, and Suaeda; slightly below the level of the insertion of the cotyledons in Beta and Spinachia ; whilst, finally, in Blitum and Chenopodium it takes place in an intermediate position.

CYCLOLOBEAE.

Beta brasiliensis, ?, B. chilensis, Hort., B. hortensis, Mill., and B. vulgaris, Moq. The details of the transition in these plants are like those of Amaranthus caudatus, the only differences being that in Beta a short cotyledonary tube is formed and there is no marked delay in the fusion of the phloem-masses in the hypocotyl.

Chenopodium ambrosoides, L., C. Atriplicis, L., C. Bonus-Henricus, L., C. Botrys, L., C. calulatum, ?, C. capitatum, Aschers, and C. scoparium, L., all resemble Amaranthus and Beta. A short cotyledonary tube occurs in C. Bomus-Henricus, C. capitatum, and C. scoparium. The bifurcation of the central cotyledonary strand takes place well within the blade of the seedleaf, but in no case is the protoxylem entirely isolated as in Amaranthus sylvestris. The $\mathrm{V}$-shaped bundle is accompanied downwards by two laterals, and their union occurs at different levels: in $C$. ambrosoides and $C$. Botrys this coalescence takes place at a level well above the cotyledonary node; in C. Atriplicis, C.Bonus-Henricus, C. calulatum, and C.capitatum the junction is at, or just above, the cotyledonary node ; finally, $C$. scoparium is remarkable in the fact that the laterals make no junction with the central strand, but come to an end.

It may also be remarked that there is no particular delay in the fusion of the groups of phloem-elements in the axis, as obtains in Amaranthus.

Atriplex hastata, L., has its transition-characters in common with many species of Amaranthus, Gomphrena, \&c. The main seed-leaf-bundle bifurcates at a relatively high level, and the separation of the two halves is so complete that the protoxylem appears in an isolated position at a level above the cotyledonary node. There is thus a close resemblance to Amaranthus sylvestris, the only difference, of degree rather than kind, in this respect being that in the last-named plant this isolation takes place at a much higher level. A minor feature of difference is that the main bundle may be accompanied in its passage down the petiole by two or three laterals on each side, not two as is the case in all the foregoing plants. These lateral strands join on to the adjacent halves of the divided central bundle at the cotyledonary node, and sometimes even in the top of the hypocotyl, a feature of resemblance to some of the foregoing plants, Gomphrena haageana for instance. Again, as in many species of Amaranthus, there is a marked delay in the union of the corresponding pairs of phloem-masses within the 
hypocotyl ; indeed, considering the advanced state of preparation in the cotyledons for the vascular rearrangements, the assumption of a proper rootstructure takes place at a surprisingly low level.

A well-marked cotyledonary tube is present.

Atriplex littoralis, L. With regard to the features under discussion this plant is practically identical with $A$. hastata.

Atriplex thamnoides, ?, which has a much smaller seedling, shows some differences. It has no cotyledonary tube, the lateral bundles fuse on

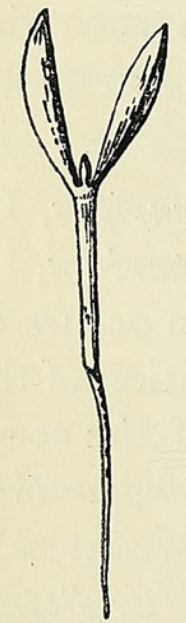

FIG. 2. Obione portulacoides.

Natural size. to the central one in the base of the blade of the cotyledons, and there is no undue delay in the fusion of the phloemmasses within the axis.

Obione portulacoides, Moq. (Fig. 2). The seed-leaves are fleshy and the behaviour of their important vascular bundles, both in the cotyledon and in the axis, is precisely like those of Atriplex hastata. The laterals, however, vary pretty much; in the lower part of a seed-leaf there are, as is usual, two, one on each side of the divided central strand; of these some may die out, especially if very small, or may branch into two before coming to an end, or they may ultimately fuse with the central strand.

Spinachia oleracea, L., very closely resembles those species of Beta examined.

Kochia trichophylla, ?. The main features of the transition strongly recall those of Calandrinia grandiflora. Each seed-leaf, in its more basal region, has the usual bifurcated strand with two laterals

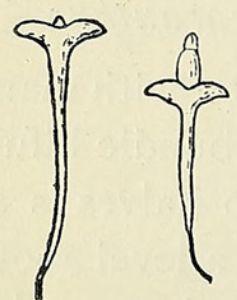

FIG. 3. Salicornia europaea. Two seedlings, one showing the epicotyl in a more advanced stage of development. Natural size. on each side of it; of these, those situated immediately on either side of the central bundle fuse with it, whilst those placed on the outermost sides die out. As in some species of Amaranthus, Atriplex, and Obione there is a delay in the fusion of the phloem in the axis, but this is not so well marked in Kochia as in Obione portulacoides.

Corispermum hyssopifolium, L., closely resembles Kochia trichophylla.

Salicornia europaea, L. The seedling of this plant (Fig. 3), and also of many other species of the genus, has two small fleshy cotyledons which fuse laterally towards the base to form a short cotyledonary tube or sheath. This tube becomes decurrent down the hypocotyl, forming a succulent 'cortex', a phenomenon exactly paralleled by the leaf-sheaths in the segments of the adult plant.

The distribution of the vascular bundles within the cotyledon is precisely 
similar to that in the leaves of the mature plant, and may be understood best by tracing the strands outwards from the cotyledonary node (Diagram 3, Fig. 6). A single trace (c. I) leaves the node and branches into three portions ; of these the median strand $(c .2)$ divides up and supplies the free leaf-tip, whilst the two lateral strands (c. 3 and $c .4$ ) curve outwards and pass

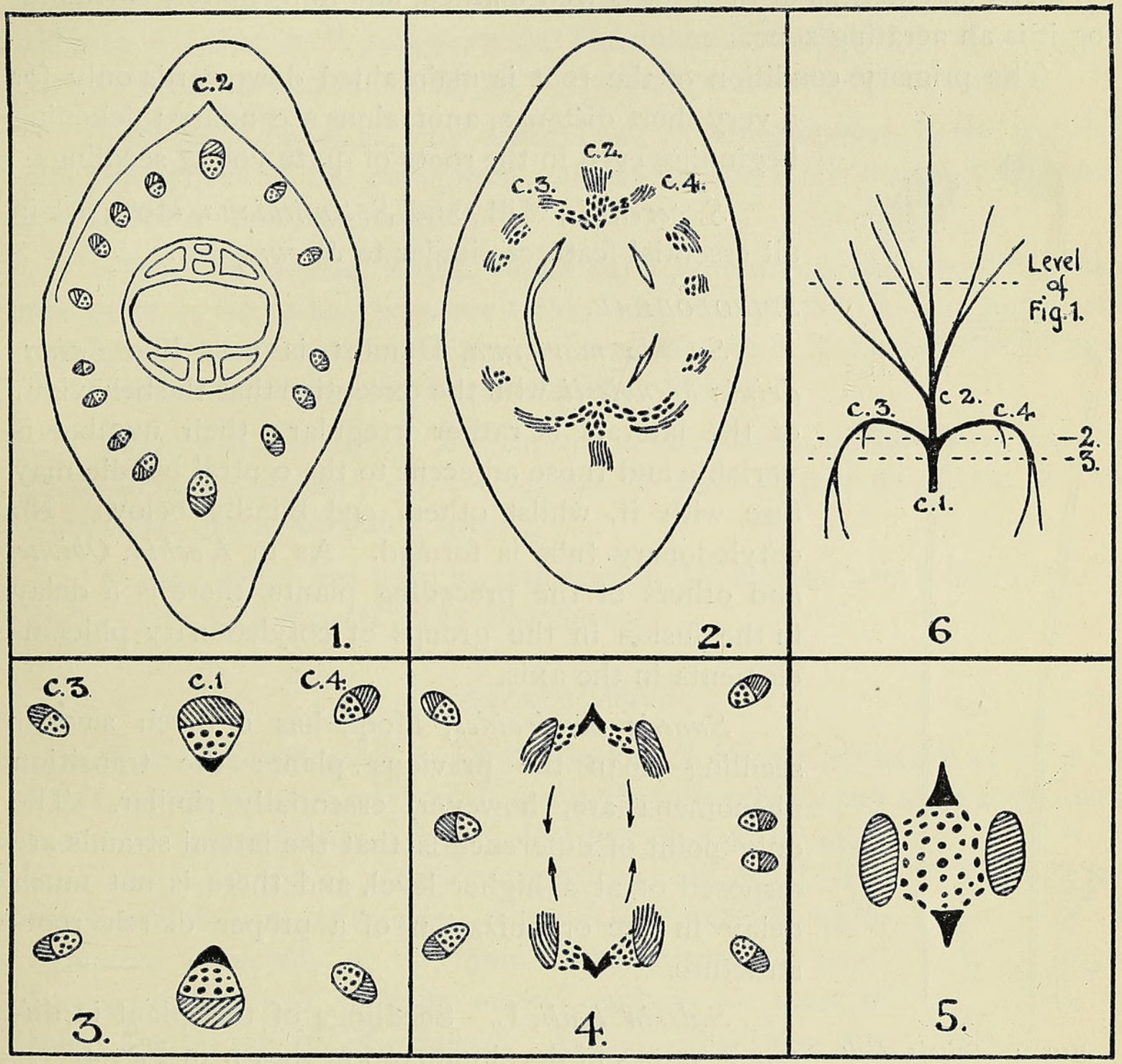

DiAgram 3. Salicornia. Fig. 6 illustrates the vascular skeleton of one side of the upper part of a seedling. The dotted horizontal lines indicate the level of the sections represented in Figs. I, 2 , and 3 .

downwards, their branches supplying the cotyledonary sheath and ultimately ending blindly in the aqueous tissue.

Tracing the strands downwards, in order to follow the transition, a section through the united cotyledons (Diagram 3, Fig. I) shows numerous bundles which are the branches of the central cotyledonary strands. Considering one side only, these bundles unite, as the sections are traced downwards, to form one strand (c. 2) which, at the node, is joined by the lateral trunks $c .3$ and c. 4. Thus from each seed-leaf one endarch collateral bundle 
(c. I) enters the hypocotyl ; these strands soon bifurcate and a well-marked rotation rapidly follows, the adjacent phloems unite, and a diarch root is organized according to type 3 .

The bundles seen in the outer regions are, of course, the branches of the lateral strands (c.3 and $c .4$ on the one side) already referred to.

The endodermis of the root is well marked, and immediately surrounding it is an aerating zone.

The primary condition of the root is maintained downwards only for

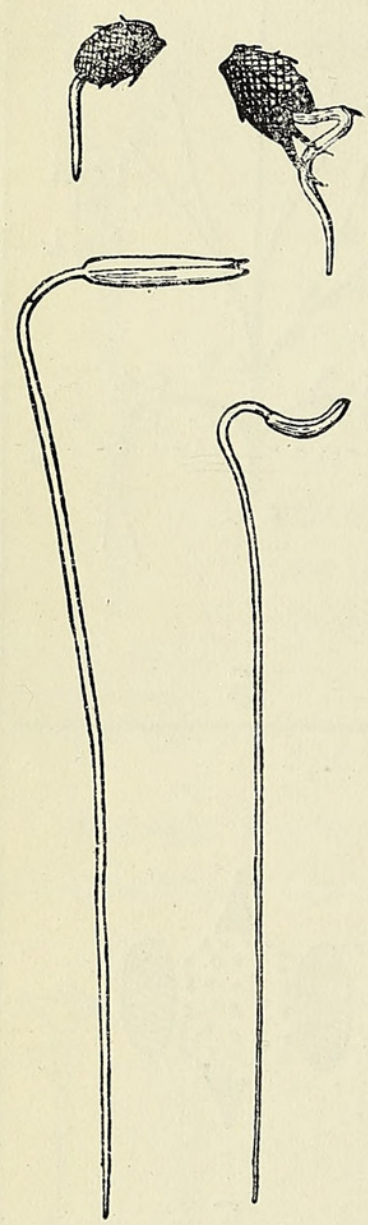

Fig. 4. Salsola Kali. In the two younger seedlings the cotyledons are still enclosed within the fruit. Natural size. a very short distance, anomalous secondary thickening beginning even in the roots of quite young seedlings.

S. perennis, Mill., and S. Smithiana, Moss, are in all essential features similar to $S$. europaea.

\section{SPIROLOBEAE.}

Suaeda maritima, Dumort, is very like Calandrinia Menziesii, with the exception that the behaviour of the laterals is rather irregular; their number is variable and those adjacent to the central bundle may fuse with it, whilst others end blindly below. No cotyledonary tube is formed. As in Kochia, Obione, and others of the preceding plants, there is a delay in the fusion in the groups of cotyledonary phloemelements in the axis.

Suaeda dendroides, Moq., has a much smaller seedling than the previous plant; the transition phenomena are, however, essentially similar. The only point of difference is that the lateral strands are disposed of at a higher level, and there is not much delay in the organization of a proper diarch rootstructure.

Salsola Kali, L. Seedlings of this plant in different stages of development are shown in Fig. 4.

With regard to the transition phenomena, they are almost precisely similar to those of Amaranthus caudatus, the only difference being that in Salsola the protoxylems of the main seed-leaf-bundles are not so fully exarch at the cotyledonary node. With regard to other features, there is a wellmarked cotyledonary tube in Salsola, and the palisade parenchyma, with its associated cells, of the upper part of the seed-leaves, which are centric in structure, is continued downwards in four columns to the cotyledonary node. 


\section{PHYTOLACCACEAE.}

Phytolacca paraguayensis, ?, in most of its transition characters is very like Amaranthus sylvestris. There is the same division of the chief cotyledonary bundle and the isolation of the protoxylem-elements which takes place in the base of the blades of the seed-leaves. The only feature of difference is that in $P$.paraguayensis the union of the two laterals with the central seed-leaf-strand is effected at the extreme base of the petioles.

Phytolacca dioica, L., only differs from $P$. paraguayensis in the fact that the two halves of the main seed-leaf-bundle are more compact and their separation is less well marked.

Phytolacca acinosa, Roxb., which has a somewhat smaller seedling, does not show, so far as has been seen, the separation of the protoxylem of the cotyledons in the seed-leaves themselves; otherwise, its vascular rearrangements are like those of the two preceding species.

Phytolacca decandra. The transition phenomena of this plant, judging from Gérard's account, ${ }^{1}$ do not appear to differ in any important feature from those of the foregoing species.

Rivina, which has been investigated by Dangeard, 2 also follows type 3 , and so also does Basella (N.O. Basellaceae).

\section{AIZOACEAE.}

Mesembryanthemum. All the seedlings of this genus are of a fleshy habit, which is more marked in some than in others, and their cotyledons are more or less adnate. This union may be nothing more than the formation of a cotyledonary tube, as in $M$. crystallinum, L.; in other cases the adnation may be quite extensive, especially in the more fleshy forms, the seedleaves being joined by their ventral surfaces for most of their length, as in $M$. Bolusii. Fig. 5 illustrates the two extreme forms of young seedlings; of the species examined, $M$. linguaeforme, $M$. tigrinum, Haw., and $M$. truncatellum, Haw., very closely resemble $M$. Bolusii, the chief differences being those of size; thus $M$. tigrinum is about half as large as $M$. Bolusii, and $M$. truncatellum

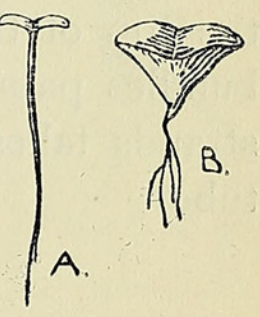

FIG. 5. A. $M e$. sembryanthemum crystallinum ; B. M. Bolusii. $\mathrm{Na}$ tural size. about one-third or a quarter the size of this same plant, also it is more rounded. $M$. crystallinum resembles $M$. tricolorum, Haw., and $M$. rhomboideum is somewhat intermediate in appearance.

The transition phenomena are like those of many of the foregoing plants, Calandrinia Menziesii for instance. In M. tricolorum, M. crystalli- 
num, and usually in $M$. linguaeforme the protoxylems of the cotyledonary strands are exarch before the bundles enter the hypocotyl. On the other hand, in $M$. filamentosa, $M$. rhomboideum, $M$. trigrimum, and $M$. truncatellum the protoxylems referred to are not fully exarch, sometimes even practically endarch, although the bundles may be opened like a V. This feature, however, is variable; thus in one seedling, e.g. of M.rhomboideum, the central seed-leaf-bundle of one cotyledon may be well divided, at a level immediately above the cotyledonary node, with its protoxylem mesarch or partly exarch in position, whilst the other bundle may show no division at all and the protoxylem endarch in position.

Before passing on, attention may be drawn to a peculiarity in some species of this genus which is unique in the plants examined.

In Mesembryanthemum Bolusii and $M$. linguaeforme, the two species with the fleshiest and largest cotyledons, the main central bundles of the seed-leaves are, for some distance above the cotyledonary node, surrounded by an irregular endodermis, not necessarily consisting of a single layer of cells, but often of two or three. In the more upper regions, the endodermis may not entirely enclose the bundle, but at lower levels, especially in $M$. linguaeforme, it is complete and singularly convincing. In $M$. filamentosa and $M$. rhomboideum this endodermis is not so extensive, but it forms a more or less complete sheath around the main bundles of the seedleaves at the cotyledonary node. In these cases an endodermis surrounds the vascular tissues of the axis before the root-structure is organized.

Tetragonia expansa, Murr. The transition phenomena do not differ in any essential feature from those of Mesembryanthemum. The main cotyledonary strands bifurcate in the base of the blades of the seed-leaves, or in the top of the petioles, and their protoxylems become exarch before the bundles pass into the axis. The fusion of the laterals with the central strands takes place at a low level, just above the top of the cotyledonary tube.

\section{NYCTAGINACEAE.}

Abronia. The seedlings of the species of this genus examined, A.umbellata and $A$. villosa, are of interest from the fact that the cotyledons are very unequal in size. Fig. 6 represents a number of seedlings of different ages of $A$. villosa; it will be observed that in the younger plants one of the cotyledons is extremely small, whilst in the older plants it approximates more closely to the larger seed-leaf. In the youngest seedling (A) the rudiment of one seed-leaf is inserted on the axis at about the same level as the well-developed cotyledon, but in older seedlings, owing to the more rapid growth of the large cotyledon, the small one appears to be inserted lower down the hypocotyl. Also it will be ob- 
served that the base of the hypocotyl, especially in the younger plants, is distinctly swollen and bears on one side a prominent peg or foot $(p)$.

Charles and Francis Darwin ${ }^{1}$ have drawn attention to these peculiarities in $A$. umbellata and $A$.arenaria, and have figured them in the former plant; they compare the swollen hypocotyl to a corm, and point out that the peg functions in rupturing the coat of the fruit.

Avebury ${ }^{2}$ also has described the seedlings of Abronia, and remarks that in the seed one of the cotyledons is almost aborted and remains quite small for some time after germination. In $A$. umbellata it afterwards becomes the largest and grows like an ordinary leaf. He further remarks that the full-grown cotyledons of $A$, arenaria are very unequal in size.

Abronia umbellata, Lam. In the seedling about to be described there was one large and one small cotyledon. The large seed-leaf (Diagram 4, c. I) has one large central bundle with many smaller ones on either side. Within the blade the central bundle divides into two and shows a certain amount of rotation, so that some, often only one or two, protoxylem elements become isolated between the two half-bundles which move apart (see Diagram 6, Figs. I-4). This is comparable to what obtains in some of the preceding plants, Amaranthus sylvestris and species of Gomphrena and Chenopodium for instance. But in no case in these plants is the isolation so well marked as in Abronia, Allionia, and other Nyctaginaceae.

At the base of the blade the condition obtaining is shown in Diagram 4, Fig. I; the laterals fuse on to the adjacent half-bundles, hence the petiole has two strands, the half-
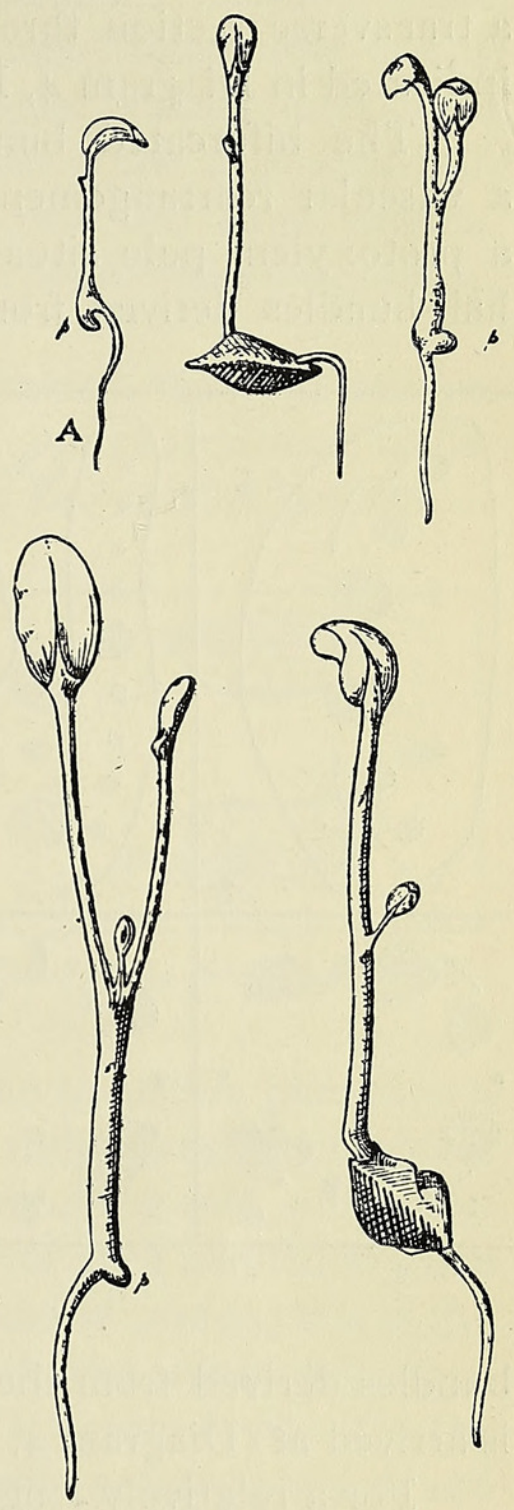

FIg. 6. Abronia villosa. Natural size.

bundles referred to above, partly facing one another and with a small group of protoxylem elements between them (Diagram 4, Fig. 2). At a lower level the two large strands divide, each into two, and clearly are in the first stage of rotation (Diagram 4, Fig. 3). In this condition they enter the axis.

Turning now to the small cotyledon $(c .2)$, which is not nearly so well

1 C. and F. Darwin: The Power of Movement in Plants. London, 1880.

2 Lubbock: On Seedlings. London, 1892. 
differentiated as the larger, the central strand behaves in exactly the same way as the corresponding bundle of $c .2$ to begin with; that is to say, it divides into halves and isolates some protoxylem in the blade. The lateral bundles are not differentiated, consisting only of desmogen. Lower down (Diagram 4, Fig. 3), these desmogen strands fuse on to the adjacent halves of the central bundle, which do not divide as in the other cotyledon. Thus a transverse section through the top of the hypocotyl has the appearance indicated in Diagram 4, Fig. 4.

The bifurcated bundles derived from the large cotyledon undergo a vascular rearrangement, as a result of which each pair gives origin to a protoxylem pole situated in the intercotyledonary plane; then the two half-bundles derived from the small cotyledon fuse on to the adjacent

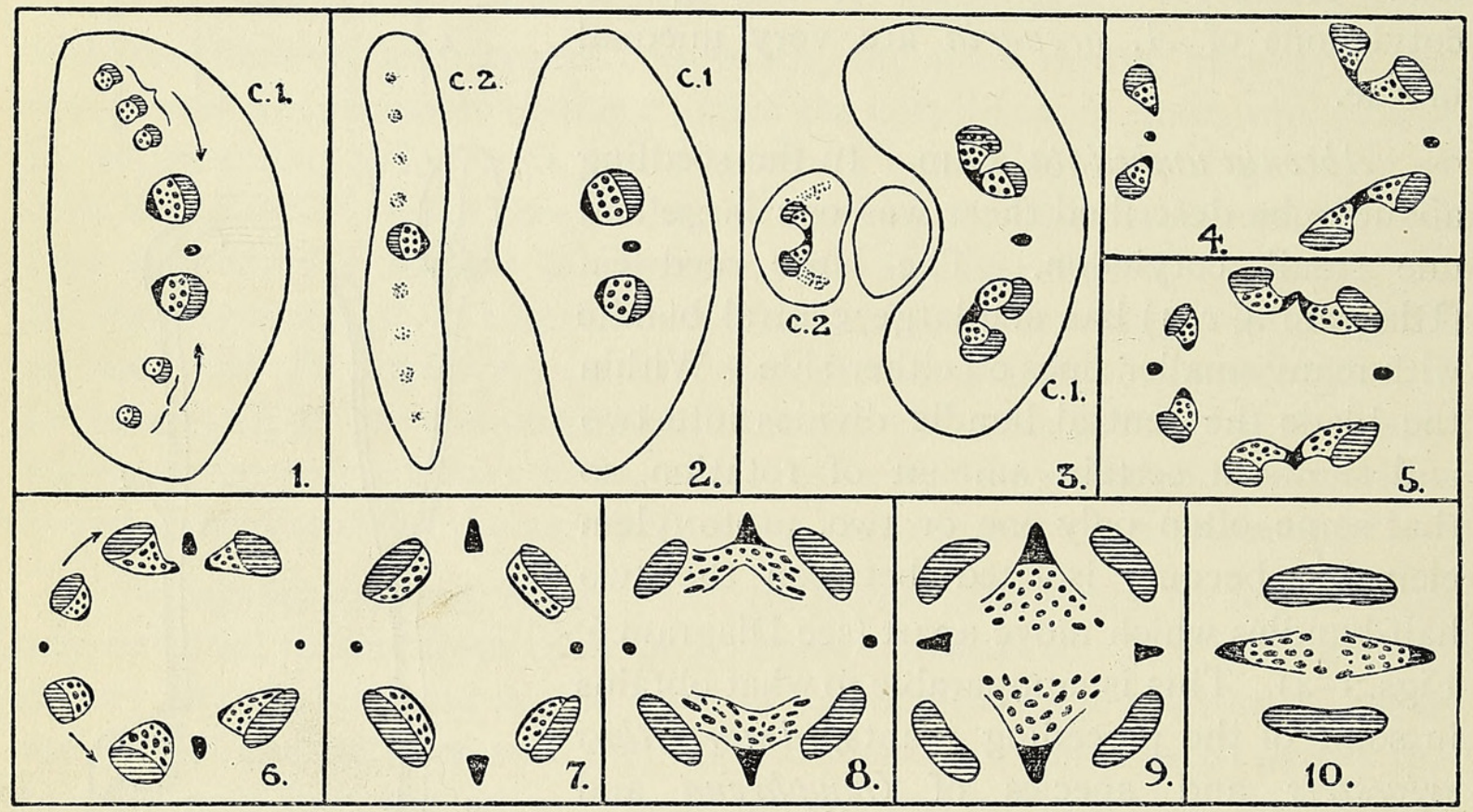

Diagram 4. Abronia umbellata.

bundles derived from the large seed-leaf, and thus a tetrarch root-structure is arrived at (Diagram 4, Figs. 5-8).

For a relatively long distance downwards the intercotyledonary xylem poles are much the stronger, but eventually a gradual addition of protoxylem elements is made to the poles in the plane of the seed-leaves, so that equality is ultimately arrived at (Diagram 4, Fig. 9). Reduction, however, may take place; in one example, below the level of the peg, the intercotyledonary protoxylem rays diminished in size and disappeared, the corresponding phloem strands united, and a well-marked diarch rootstructure resulted (Diagram 4, Fig. IO).

Minor variations in these changes may occur; thus the division of the two half-bundles of the large cotyledon may take place in the upper part of the hypocotyl, and not in the petiole of the seed-leaf, and the union of the 
half-bundles derived from $c .2$ may unite with the corresponding strands from the other cotyledon, immediately before, or simultaneously with, the bifurcation of the latter (Diagram 5, which compare with Figs. 4 and 5 of Diagram 4). Finally, the root does not always show a reduction from tetrarchy to diarchy.

Abronia villosa, Wats. The vascular rearrangements resemble those of $A$. umbellata very closely; in fact the only difference found was in one example of $A$. villosa, in which only the two innermost laterals fused on to the neighbouring halves of the divided central bundle of the large seed-leaf. The others, two on each side, united together to form two large strands, so that the result was exactly the same as in $A$. umbellata (Diagram 4, Fig. 3).

In all the examples of these two species examined, the bundles from the larger cotyledon gave origin to three poles of the tetrarch root, whilst the bundles from the smaller seed-leaf gave rise to the smaller pole; this irrespective of the age of the seedling. It may also be remarked that the continuity between the isolated protoxylem elements in the petioles of the seed-leaves and the corresponding poles of the root may be interrupted, so that they are almost if not quite impossible to trace. This is doubtless due to the growth in length either rupturing or pulling together the soft walls of the annular vessels.

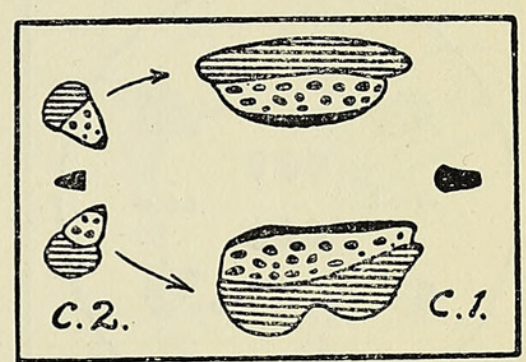

Diagram 5. Abronia umbellata.

Allionia albida, Walt. The main features of the transition phenomena of this plant resemble those of Abronia, the chief differences which obtain being connected with the formation of those poles of the root situated in the intercotyledonary plane. The central bundle of each cotyledon gives rise, in the blade of the seed-leaf, to an isolated strand of protoxylem in the same way as in Abronia (Diagram 6, Figs. I-4). In the upper regions of the petiole of each seed-leaf several strands occur (Diagram 6, Fig. 5): the two large bundles formed by the division of the main cotyledonary strand (b. I and b. 2); two or three laterals on the outer sides of each of these $(a)$; a few small bundles situated between the first two $(e)$, and the group of protoxylem elements (c. I). On tracing these downwards their number becomes less; thus the small medianly placed bundles $(e)$ unite with the adjacent large ones, the half-bundles of the main cotyledonary strand, and the lateral strands unite together until there are but one or two on either side. There is also in the centre a group of protoxylem-elements (c. I and c. 2) which are never numerous.

Either at, or immediately above, the cotyledonary node, or in the hypocotyl, the laterals $a$ fuse on to the neighbouring half-bundles (Diagram 6, 
Fig. 6), so that in the upper region of the hypocotyl (Diagram 6, Fig. 7) there occur two groups of protoxylem (c. I and $c .2$ ), four large bundles derived from the cotyledons $(b, 1$ and $b .2$, and $b .3$ and $b .4)$, and six plumular strands which soon fuse to form two $(d$. I and $d$. 2, Diagram 6 , Fig. 8). Tracing these bundles downwards, their behaviour is seen to be

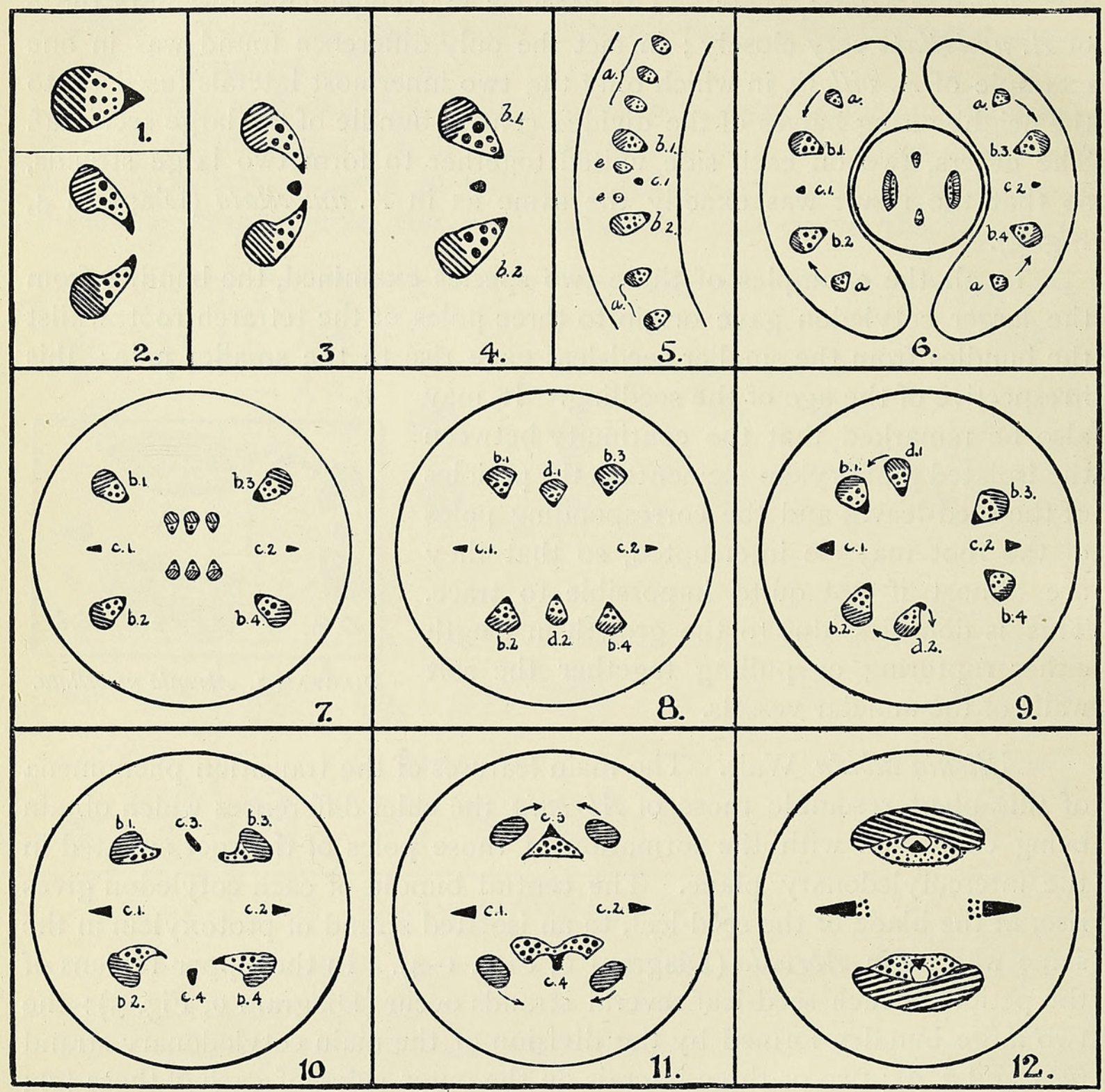

Diagram 6. Allionia albida.

very complicated; the protoxylems $c$. I and $c .2$ retain their position, but the bundles $b . \mathrm{I}, d$. I, and $b .3$ anastomose very freely, and so also do the corresponding strands on the other side. Concurrently the bundles $b$. I and $b .3$, and $b .2$ and $b .4$, show certain rotatory movements which tend to bring their protoxylems into the intercotyledonary plane and into the exarch position, but for some space downwards these movements lead to nothing definite owing to the presence of the strands $d$. I and $d .2$, which 
may give off branches which join on to the adjacent bundles. Eventually the plumular strands $d$. I and $d .2$ join on to one of the bundles situated on their flanks (Diagram 6, Fig. 9), and a definite rotation of the protoxylems of the bundles $b$ takes place (Diagram 6, Fig. I0); thus there is organized a tetrarch root-structure (Diagram 6, Fig. II), which, however, in a very short vertical distance downwards gives place to a diarch arrangement. The phloem and metaxylem of $b . I$ and $b .3$, and $b .2$ and $b .4$, effect a junction and enclose the protoxylems which were derived from these same bundles (Diagram 6, Figs. II and I2). These protoxylems die out and thus there supervenes a diarch root-structure, the groups of tracheae $c .1$ and $c .2$, which have gradually been increasing in number, forming the permanent protoxylems.

Mirabilis longiflora, L. The seedlings of this plant (Fig. 7) are large and have prominent epigeal cotyledons, often unequal in size, with long petioles inserted on a rather massive hypocotyl, at the base of which there is a conspicuous peg $(p$.$) .$

The essential features of the transition phenomena resemble those of Allionia albida; but the structure of the hypocotyl is exceedingly complicated and is illustrated in Diagram 7 .

The vascular changes in the cotyledons are so like those of Allionia that no further description
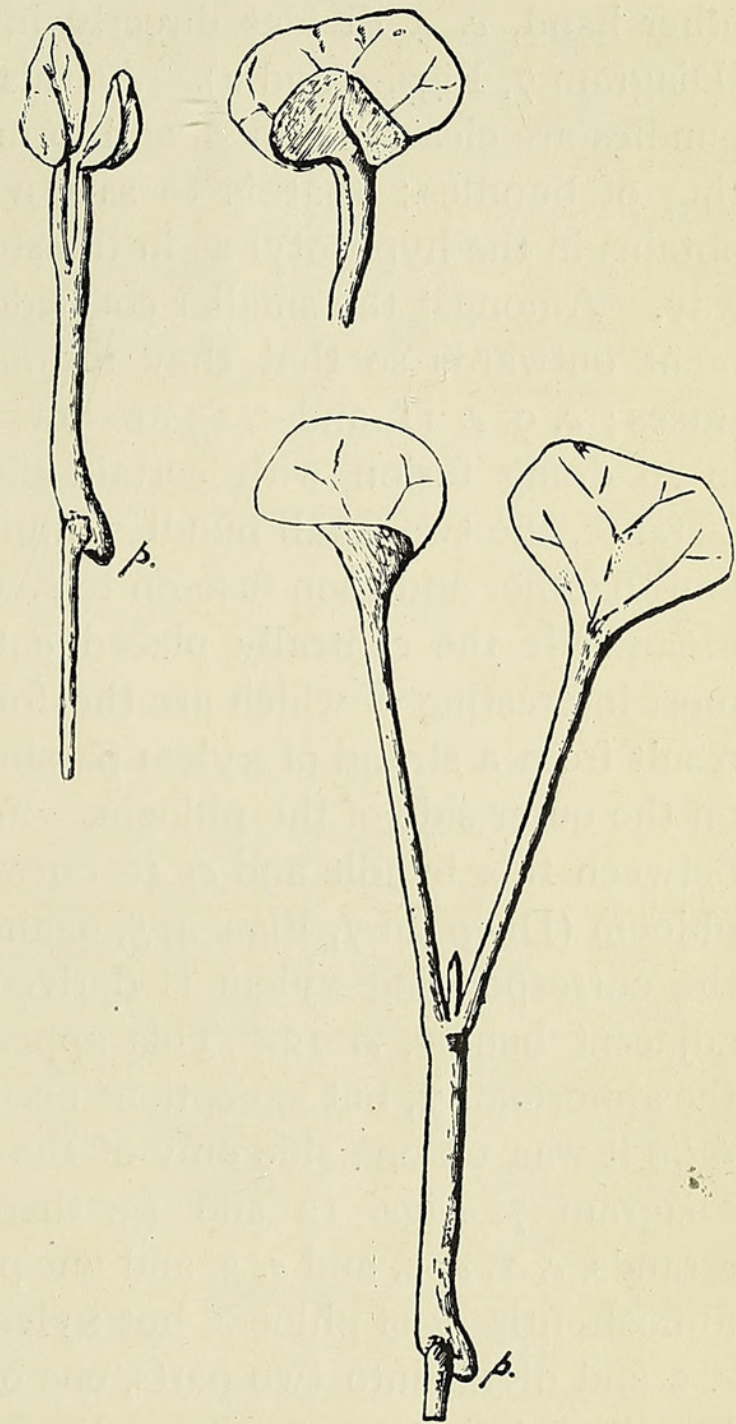

FIG. 7. Mirabilis longiflora. Natural size. is necessary (see Diagram 6, Figs. I-6). At the top of the hypocotyl, as in Allionia, there obtain two isolated groups of protoxylem-elements--four large vascular bundles (c. I, c. 2, c. 3 , and $c .4$ ) derived from the cotyledons, and two masses of plumular vascular tissue $(p)$. Tracing these bundles downwards, the plumular vascular tissue passes outwards between the strands $c .1$ and $c .3$, and $c .2$ and $c .4$, deploys on either side, and breaks up into isolated vascular strands $(p)$, which sometimes consist only of phloem (Diagram 7 , Figs. 2, 3, and 4). Concurrently the 
large bundles $(c . \mathrm{I}-c .4)$ give off branches of phloem and xylem which follow the path taken by the plumular tissue and reinforce it as it were. Hence, although these plumular bundles are marked $p$ in the Diagram, in order to indicate their nature, it must be understood that at levels below the second figure of Diagram 7 they contain also vascular elements derived from the cotyledonary strands. During these changes the original bundles, c. I, c. 2, c. 3, and c. 4, have each divided up into three; thus $c$. I gives origin to $c .5$ and $c .6, c .6$ again dividing to form $c .15$ and $c .16$; on the other hand, c. 4 divides directly into three, namely $c$. IO, c. II, and $c$. I 2 (Diagram 7, Figs. 3 and 4). At this level (Diagram 7, Fig. 4) the plumular bundles are clearly defined, and form a zone surrounding the cotyledonary ring of bundles; that is to say, a similar anomaly of scattered bundles obtains in the hypocotyl as in the stem, although arrived at in a different way. Amongst the smaller cotyledonary bundles there is a general movement outwards so that they ultimately come into line with the plumular traces; c. 9, c. II, and c. I5 are among the first to show this tendency, and in so doing fusion with certain plumular strands may take place. For instance, the two small bundles immediately above $c$. I 5 (Diagram 7 , Fig. 5) join together and then fuse on to $c$. 15 ; also $p .5$ and $c$. I I effect a junction. Meanwhile the centrally placed cotyledonary bundles show changes, the most interesting of which are the formation of bicollateral structures which result from a strand of xylem passing from the normal wood to a position on the outer side of the phloem. For example, in $c .7$ such a strand passes between this bundle and $c$. I 6 outwards, and rests on the outer side of the phloem (Diagram 7, Figs. 4, 5, 6, and 7). On the opposite side of the axis the corresponding xylem is derived from $c$. I3, and comes to rest on the adjacent bundle, $c$. I2. This appears to be the usual mode of origin of the abnormality, but exceptions occur; thus in another example of $M$. longifolia it was, on one side only of the axis, arrived at in a modified way. In Diagram 7, Figs. 12 and I3, there are represented three cotyledonary strands, c. I, c. 2, and $c .3$, and one plumular strand, $p$. This latter consists almost entirely of phloem, but xylem-elements pass outwards from $c$. I and c. 2 and divide into two parts, one of which accompanies and completes the bundle $p$ (Diagram 7, Fig. 13), and the other for the moment is isolated, then it is joined by a strand of phloem from $c$. 2, so that there is formed, between $c$. I and $c .2$, a collateral bundle showing reversed orientation, which quickly effects a junction with $c$. I.

Directly after these bicollateral bundles have been organized there is a junction of three bundles to form one situated in the intercotyledonary plane: thus $c .16, c .7$, and $c .8$ join to form $c .17$, and $c .13$, after its division into two, combines with $c$. I 2 to form $c .18$ (Diagram 7 , Figs. 4, 5, and 6). Thus there are formed two large bicollateral bundles with xylem on both sides of the phloem, and in them the extension outwards of the normally 


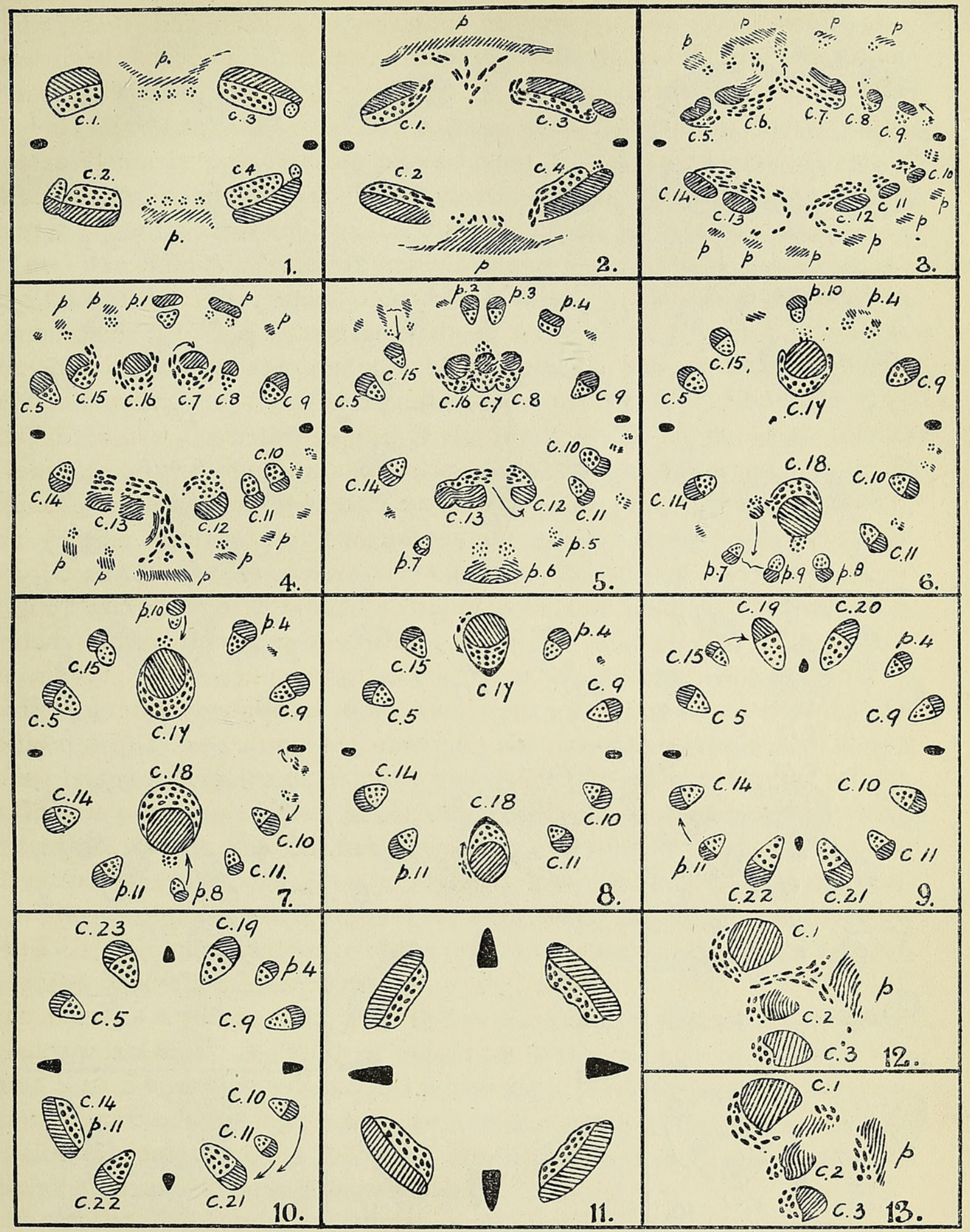

Diagram 7. Mirabilis longiflora. Explanation:-c. indicates the bundles derived from the cotyledons ; $p$. represents those of plumular origin. Whenever one important bundle fuses with another, or divides into two, the resulting strands are indicated, when necessary, by the next available higher figures. For instance, $c$. I (Fig. I) divides into two; the next available numbers are $c .5$ and $c$. 6 , so these are used to represent the two branches (Fig. 3). Again, c. I7 (Fig. 8) divides into c. I9

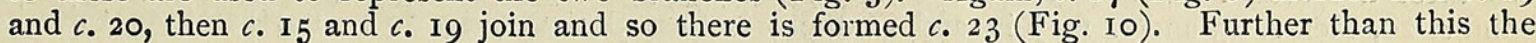
numbers are meaningless. 


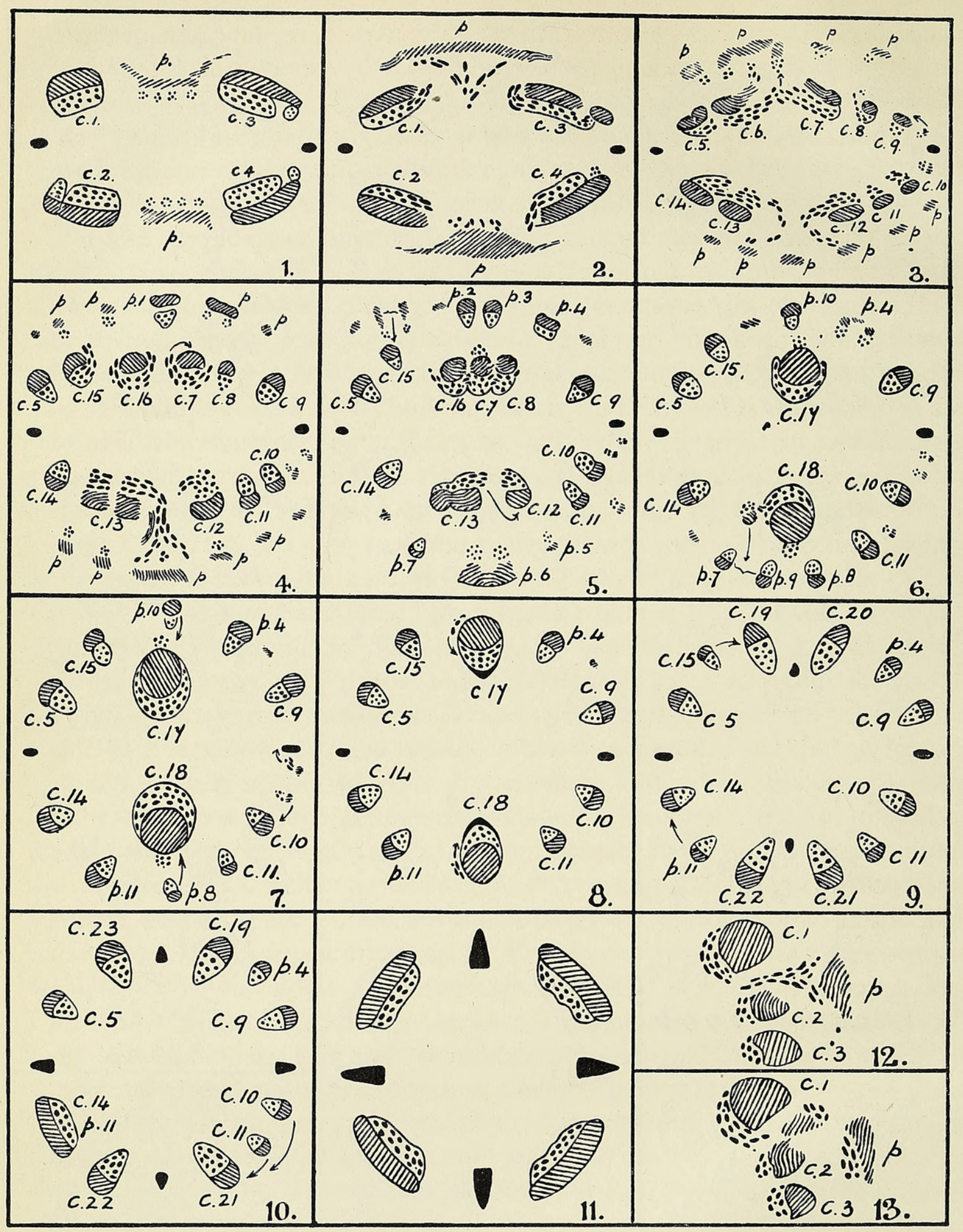

Diagram 7. Mirabilis longiflora. Explanation:-c. indicates the bundles derived from the cotyledons ; $p$. represents those of plumular origin. Whenever one important bundle fuses with another, or divides into two, the resulting strands are indicated, when necessary, by the next available higher

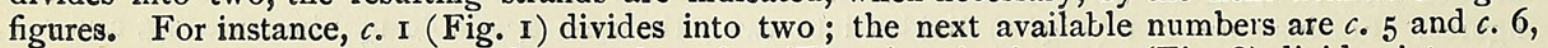
so these are used to represent the two branches (Fig. 3). Again, c. I7 (Fig. 8) divides into c. I9 and $c_{.} 20$, then $c_{0} I_{5}$ and $c_{0} 19$ join and so there is formed $c_{0} 23$ (Fig. IO). Further than this the numbers are meaningless. 
placed xylem may be so extensive as to make them almost concentric (Diagram 7, Figs. 6 and 7), a tendency shown also by the bundles of the stem. ${ }^{1}$

While these changes have been taking place the plumular strands have not been idle; $p$. I divides into two, $p .2$ and $p .3$, but only to rejoin ( $p$. Io, Diagram 7 , Fig. 6). Also, the strands $p .4$ and $p .6$ (Diagram 7 , Fig. 5) branch into two; the two branches of the former recombine (Diagram 7 , Figs. 6 and 7$)$, but not so the latter ( $p .8$ and $p .9)$. The changes at lower levels are much less complex; the large strand $c$. I 8 gives off a slender lateral branch (Diagram 7 , Fig. 6 ) which fuses on to $p .7$ and $p .9$, these three forming the larger bundle, $p$. I I (Diagram 7, Fig. 7). Further, there is a general clearing up of the smaller plumular traces; $p$. Io joins on to c. $\mathrm{I} 7$, similarly $p .8$ unites with $c$. $\mathrm{I} 8$, the small strand on the right side of c. 10 joins with this bundle, and the xylem of the similar strand just below the right-hand protoxylem joins on to the protoxylem, whilst its phloem comes to an end (Fig. 7). Finally, the abnormally placed xylem elements in $c .17$ and $c$. 18 creep inwards and join on to the normal wood (Diagram 7 , Fig. 8). Thus there is formed a ring of collateral bundles, some of which consist mostly of cotyledonary vascular tissue and two, $p .4$ and $p$. II, mostly of plumular vascular tissue, from which the root-structure is organized. Of the root-structure, two xylem poles, those in the plane of the cotyledons, are already in position; the other two are formed in this wise: the two large bundles, $c$. I7 and $c$. I8 (Diagram 7 , Fig. 8), divide, each into two; the halves do not show any rotation comparable to what obtains in so many of the foregoing plants, but move apart, leaving the protoxylem isolated (Diagram 7, Fig. 9). There is then a general centripetal displacement, so that the bundles intervening between the four groups of protoxylem-elements fuse to form four large strands, and thus a tetrarch root-structure is organized (Diagram 7 , Fig. II).

Leaving out of consideration the extraordinary series of anastomoses, it will be seen that the type of transition is the same as in Allionia. In brief, two protoxylems are isolated in the seed-leaves themselves, the cotyledonary traces enter the axis and form four large bundles (c. I-c. 4), the corresponding pairs of which give origin to the two protoxylem poles situated in the intercotyledonary plane.

The main differences between the two plants are these: whereas in Allionia the tetrarch arrangement gives place to a diarch root-structure, in Mirabilis the tetrarch structure, so far as our observations show, persists; but this is not constant for the genus, for in $M$. divaricata reduction to diarchy takes place, and the same also applies to $M$. multiflora. Further, in Allionia the anastomoses between the bundles in the hypocotyl, although

1 Solereder : Systematic Anatomy. Oxford, vol. ii, 1908, p. 647.

O 2 
complex, are not nearly so complicated as in Mirabilis, nor do the bundles form two distinct zones.

$M$. divaricata, Lowe, in essential features is like $M$. longiflora, only two points of difference having been observed: in $M$. divaricata the bundles corresponding to $c .17$ and $c$. I 8 in Diagram 7 are never collateral, and the tetrarch root-structure becomes reduced to diarch.

M. multiflora, A. Gray. Out of a large sowing there was obtained but one seedling, which was of interest owing to the small size of one cotyledon (Fig:,8) and to the presence of a prominent peg. Unfortunately an accident happened to the series of microtomed sections, so that we have no observations to make regarding the structure of the upper part of

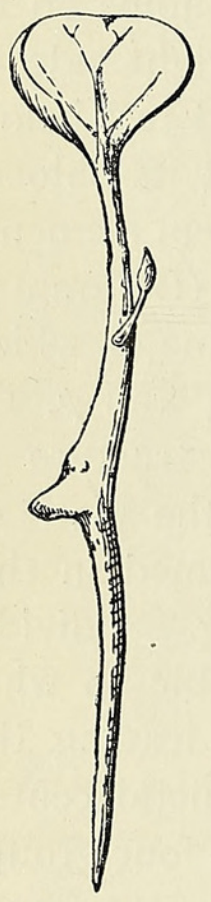

FIG. 8. Mirabilis multiflora.

Natural size. the hypocotyl; sufficient preparations remained, however, to indicate pretty strongly that the fundamental features of the transition are essentially the same as in other species of Mirabilis. As has already been remarked, the tetrarch root-structure becomes reduced to diarch.

This also is true of $M$. Falapa, for Van Tieghem ${ }^{1}$ found that out of ten seedlings examined six had diarch roots and four tetrarch.

From Gérard's ${ }^{2}$ account it is clear that the transition phenomena of $M$. Falapa are of the same nature as those of the species described above, particularly $M$. divaricata, for $M$. Falapa shows the same reduction of tetrarchy to diarchy.

With regard to the behaviour of the traces within the. hypocotyl we are not in agreement. Gérard observed the double series of bundles (Diagram 7, Fig. 5), but he considered that those of the cotyledonary series, not the plumular, moved outwards to form the outer zone (see Diagram 7, Figs. 2 and 3). Apparently also Gérard did not make any observations on the behaviour of the bundles within the cotyledons, and therefore did not realize that the transition really beginsor ends, according to the direction the tracing is done-in the seed-leaves; consequently we do not agree that the protoxylems of the root play no part in the orientation of the bundles.

\section{Summary and Conclusion.}

I. The transition phenomena of all the seedlings examined of the Natural Orders Portulacaceae, Caryophyllaceae, Amarantaceae, Chenopodiaceae, Phytolaccaceae, and Aizoaceae follow Van Tieghem's type 3; whilst those of the Nyctaginaceae follow a course which at first sight appears distinctive, but is clearly a modification of this same type. 
2. In all the first-named orders the differences which obtain between the various species are chiefly connected with the levels at which the transition phenomena first appear and end, and the level at which the lateral strands of the seed-leaves effect a junction with the divided central cotyledonary bundle.

3. With regard to the first point, the plants may be divided roughly into three classes:

A. The bundle from each cotyledon enters the hypocotyl in an undivided state, with the protoxylem in the endarch position. Examples: Claytonia perfoliata, Pupalia purpurea, Salicornia europaea, S. perennis, and $S$. Smithiana.

B. The main seed-leaf-bundle bifurcates at a level just above the cotyledonary node. Examples: Dianthus barbatus, D. arenarius, Lychnis Viscaria, Gypsophila Saxifraga, Saponaria cerastoides, S. Vaccaria, S. vulgaris, Tunica prolifera, Cevastium perfoliatum, Stellaria graminea, Mesembryanthemum spp., Cucubalus baccifera, and Spergularia salina. Of these the first one is intermediate between Classes A and B, whilst the last two are intermediate between Classes B and C.

C. The main seed-leaf-bundle bifurcates at a much higher level, sometimes even in the base of the blade of the cotyledon.

All the other species examined, and these comprise the majority, fall into this class ; of them, the following show the isolation of the protoxylemelements either in the petioles, e. g. Atriplex hastata, or in the lower regions of the blade of the cotyledon, e.g. Amaranthus sylvestris, Gomphrena Haageana, G. globosa, Phytolacca paraguayensis, and $P$. dioica.

This feature is not constant in the genera; thus $A$. sylvestris was the only species of the genus Amaranthus which exhibited it; also it was not observed in Phytolacca acinosa.

Another character shown by some of the members of this class is the delay in the fusion of the phloem-masses of the otherwise normal diarch root-structure. Examples: All species of Amaranthus and Beta, Atriplex hastata, A. thamnoides, Obione portulacoides, Kochia trichophylla, and Corispermum hyssopifolium.

4. With regard to the second point, relating to the lateral bundles, it may be remarked that in very few cases are these strands corresponding in importance to the laterals, say, of Dahlia Merckii; also it is rather difficult to make a satisfactory classification, for much depends on whether the seedleaves have well-marked petioles or not. Roughly, the plants examined fall into two categories:

A. Those in which the lateral bundles of the blade do not extend down to the cotyledonary node but fuse on to the main seed-leaf-strand at the top of the petiole or a relatively high level. This is constant in the Portulacaceae, and in the Caryophyllaceae with the exception of Saponaria. 
S. cerastoides conforms to type, whilst S. Vaccaria and $S$. vulgaris fall into the next category. Of the Aizoaceae, Mesembryanthemum, the cotyledons of the species of which show no differentiated petioles, is to be included in the present class, whilst Tetragonia is to be placed in the next.

B. Those in which the lateral strands, generally one on either side of the main bundle, extend down as far, or nearly as far as the insertion of the seed-leaves, or in some cases even into the hypocotyl, before fusion with the central strand takes place. Examples: The Amarantaceae, with the exception of Amaranthus sylvestris and species of Gomphrena, which approach Class A; the Chenopodiaceae, with the exception of Chenopodium ambrosoides, C. Botrys, Atriplex thamnoides, Kochia, Corispermum, and Suaeda dendroides, which belong rather to the previous class; and, lastly, the Phytolaccaceae.

5. A comparative examination of these facts shows that differences sometimes occur in different examples of one species; the dissimilarities between some species of a genus may be greater than the differences between genera ; further, Pupalia, Claytonia, and Salicornia, genera widely separated, show very close resemblances.

6. With regard to the Nyctaginaceae, the transition phenomena may be looked upon as a modification of type 3, for after each cotyledonary strand has bifurcated and isolated within the blade of the seed-leaf those protoxylems situated in the cotyledonary plane, corresponding bundles from opposite sides together form the two protoxylem poles situated in the intercotyledonary plane. To this, however, Abronia is an exception, three poles of the root-structure being formed from the bundles of the larger cotyledon, and the remaining pole from the vascular tissue derived from the smaller seed-leaf.

7. A connexion between the Nyctaginaceae and the other Natural Orders of the Cohort may be traced. For example, in Amaranthus sylvestris, Gomphrena globosa, G. Haageana, Phytolacca paraguayensis, and P. dioica, the protoxylem is isolated in the cotyledons ; in Amaranthus, Gomphrena, and other plants there is, in the axis, a delay in the fusion of the four phloems ; in other words, for a certain distance downwards the structure is incompletely tetrarch. In this connexion it will be remembered that it is not at all uncommon for the initial tetrarch structure in the Nyctaginaceae to be reduced to diarch.

8. Without entering into any theoretical considerations-they will be published later-it may be pointed out that the Nyctaginaceae haye by far the largest seedlings as compared with the other Natural Orders of the Cohort; that the vascular bundles of the large cotyledon of Abronia form three of the four poles of the root-structure, the remaining one being from the traces of the small seed-leaf; and that in the much smaller seedlings of the orders other than the Nyctaginaceae a difference is often found in the 
structure of two seedlings of a genus which are of different sizes. Thus the seedling of Saponaria Vaccaria is much larger than that of S. cerastoides; in the former plant the laterals fuse on to the central bundle of the seed-leaf at a much lower level than in the latter plant. Spergularia salina and Spergula arvensis, Atriplex littoralis and A. thamnoides, Suaeda maritima and $S$. dendroides, and Phytolacca acinosa and P. dioica are further examples. Also it may be mentioned that amongst the smallest seedlings examined were those placed in Class A (par. 3), and these exhibited the simplest structure. These facts, together with others of similar nature observed in other classes-for instance, the Gymnosperms-suggest that the transition phenomena may depend on the relative abundance and the distribution of the cotyledonary vascular supply, which is in turn influenced by various factors. This will receive more particular attention in our next contribution to the subject.

9. With regard to features of interest not directly connected with transition phenomena, the presence of an endodermis around the cotyledonary bundles of certain species of Mesembryanthemum may be referred to.

In conclusion we desire to express our thanks to Mr. Hales, the Curator of the Chelsea Physic Garden, for his never-failing kindness in rearing seedlings for our use. 


\section{$2 \mathrm{BHL}$ Biodiversity Heritage Library}

Hill, T. G. and De Fraine, E. 1912. "On the seedling structure of certain Centrospermae." Annals of botany 26, 175-199.

https://doi.org/10.1093/oxfordjournals.aob.a089384.

View This Item Online: https://www.biodiversitylibrary.org/item/236773

DOI: https://doi.org/10.1093/oxfordjournals.aob.a089384

Permalink: https://www.biodiversitylibrary.org/partpdf/319901

\section{Holding Institution}

Smithsonian Libraries

\section{Sponsored by}

Biodiversity Heritage Library

\section{Copyright \& Reuse}

Copyright Status: Not in copyright. The BHL knows of no copyright restrictions on this item.

This document was created from content at the Biodiversity Heritage Library, the world's largest open access digital library for biodiversity literature and archives. Visit BHL at https://www.biodiversitylibrary.org. 